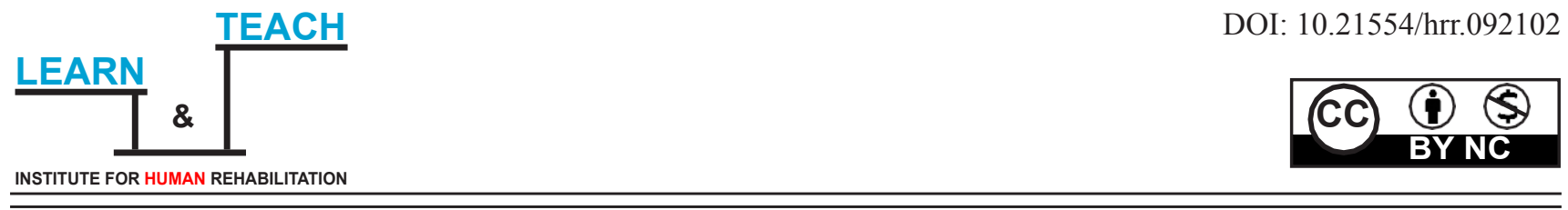

\title{
FREQUENCY AND POPULATION-GENETICS ANALYSIS OF CONGENITAL ANOMALIES DISTRIBUTION IN TUZLA CANTON NEWBORNS
}

Original scientific paper

\author{
Aldijana Avdic ${ }^{1}$, Rifet Terzic ${ }^{1}$, Vesna Hadziavdic ${ }^{1}$, Suad Siranovic ${ }^{1}$, Snjezana Hodzic ${ }^{1}$, \\ Amela Hercegovac ${ }^{1}$, Amela Jusic ${ }^{1}$ \\ ${ }^{1}$ Department of Biology, Faculty of Natural Sciences and Mathematics, University of Tuzla, Bosnia and Hercegovina
}

Received: 2020/3/14

Accepted: $2021 / 8 / 11$

\begin{abstract}
Aim of this paper was to determine the frequency of congenital anomalies in a sample of newborns of Tuzla Canton and as well as their distribution according to gender, mother's age and marital distance category. Research was undertaken using the retrospective analysis on the Clinic for Gynecology and Obstetrics of University Clinical Center in Tuzla. By analyzing medical documentation of 17223 newborns, we determined the frequency of congenital anomalies of 5.24\%. Highest frequency of congenital anomalies was found in the newborns whose mothers are older than 35. It was found that the frequency of congenital anomalies in the observed population is within the range of variation of this parameter with data from the literature.
\end{abstract}

Keywords: Congenital anomalies, newborns, Tuzla Canton

\section{INTRODUCTION}

According to the World Health Organization (WHO), congenital anomalies are defined as structural or functional anomalies occurring during the intrauterine life and can be recognized prenatally, during the birth and sometimes after the birth (WHO, 2016). They are also called innate damage, innate disorders or innate malformations. Estimated $6 \%$ of newborns are born with congenital anomalies which resulted in hundreds of thousands related deaths. However, the true number of cases can be much higher because statistics does not include aborted pregnancies and stillborn children. Some innate anomalies can be treated surgically and non-surgically, for example cleft lip and cleft palate, limb changes and hernias. Other, including heart damage, damage of neural tube and Down syndrome, can cause lifetime consequences. Congenital anomalies are one of the main causes of global disease load, and the countries with low and medium income are especially at risk (WHO, 2016.). Despite the great importance of knowing the genetic structure of the population with regard to certain congenital anomalies, the relevant data in the newborn population of Tuzla Canton are fragmentary and insufficient, and the assessment of the frequency of anomalies, especially those with a hereditary basis, is still largely based on research in highly developed countries. Exception in that regard are the researches of epidemiological and clinical characteristics of congenital anomalies of Tuzla Canton newborns (Skokic \& Nevacinovic, 2005). There is a lack of wider population genetics researches of medically most interesting congenital anomalies, as well as possible influences and degree of isolation of some parts of wider population and eventual occurrence of heterosis.

\footnotetext{
Correspondence to:

Aldijana Avdic, Department of Biology, Faculty of Natural Sciences and Mathematics, University of Tuzla, Bosnia and Hercegovina Tuzla, Bosnia and Herzegovina

E-mail: aldijana.tursunovic@gmail.com
} 
It can be concluded that researches of congenital anomalies in newborns of Tuzla Canton are still methodologically heterogeneous, insufficient and incomplete and targeted at smaller samples of individual narrower populations. This paper gives systematized data about frequency of congenital anomalies in newborn population of Tuzla Canton as well as the influence of possible exogenous and endogenous factors on the occurrence of those anomalies. Aim was to determine the distribution of observed anomalies according to gender, distribution of the anomalies regarding the age of mother, influence of prenatal diagnostics on the frequency of congenital anomalies, and to determine the relation between the marital distance (as the heterosis factor) and frequency of the observed anomalies.

\section{MATERIALS AND METHODS}

Results of this paper are based on retrospective analysis of 17233 newborns sample (8958 male and 8264 female). One newborn was of nondifferential gender and was not included in statistical processing because of the gendered subsample analysis. The statistical analysis is based on 17222 newborns, 15946 were full term babies and 1276 were born prematurely, in Tuzla canton during time period from 01.01.2007. to 31.12.2010. Data from medical histories and protocol books of the Clinic for Gynecology and Obstetrics of the University Clinical Center in Tuzla were used for the research. For each newborn, the collected data set for analysis contained the following components: newborn sex, year of birth, body length and weight, birth order, blood type and Rh factor, possible presence of any of the recorded congenital anomalies, and parental data. Available data are systematized in Microsoft Excel 2010 , according to baby's gender, mother's age, whether the kid was carried full term or born prematurely, and then they were statistically processed (Garrett, 1962). Totally, 30 congenital anomalies were observed. In the statistical processing, standard methods of descriptive statistics were used. Data processing was performed in the computer system SPSS ${ }^{\circledR}$ Statistics 17.0 and Statistica 8.0 StatSoft Inc. We used parametric and non-parametric significance tests $(\chi 2$-test, Student t-test) to test statistical significance. Marital distance is the spatial distance (in kilometers) between the place of birth of father and place of birth of mother. It was calculated by using the geographical maps in 1:300 000 scale and appropriate ratios. The obtained data on marital distance were used to analyze its possible impact on the frequency of observed anomalies.

\section{RESULTS}

In the period 01.01.2007. - 31.12.2010. total of 17223 newborns were born in the area of TK. In total sample examined, it was determined that 903 newborns have some of the observed congenital anomalies (5.24\%). A total of 32 types of congenital anomalies were reported. In this paper, 30 types of congenital anomalies were analyzed, and it was determined that 882 newborns have some of the analyzed congenital anomalies $(5.12 \%)$, as shown in Table 1 .

Table 1. Relative frequency (\%) of congenital anomalies observed in total sample of newborns of Tuzla Canton (Bosnia and Herzegovina)

\begin{tabular}{|c|c|c|c|c|c|c|c|c|c|}
\hline \multirow[b]{2}{*}{ Congenital anomaly } & \multicolumn{2}{|c|}{$\begin{array}{c}\text { Prematurely born } \\
\text { newborns }\end{array}$} & \multicolumn{2}{|c|}{$\begin{array}{l}\text { Full term } \\
\text { newborns }\end{array}$} & \multicolumn{2}{|c|}{ Total } & \multicolumn{2}{|c|}{ Total } & \multirow{2}{*}{$\begin{array}{r}\text { Total } \\
17222\end{array}$} \\
\hline & $\underset{670}{\mathbf{M}}$ & $\begin{array}{c}\mathbf{F} \\
606\end{array}$ & $\begin{array}{c}\text { M } \\
8288\end{array}$ & $\underset{7658}{\mathbf{F}}$ & $\begin{array}{c}\mathbf{M} \\
8958\end{array}$ & $\begin{array}{c}\mathbf{F} \\
8264\end{array}$ & $\begin{array}{c}\text { Prematurely } \\
\text { born } \\
\text { newborns } \\
1276 \\
\end{array}$ & $\begin{array}{c}\text { Full term } \\
\text { newborns } \\
15946\end{array}$ & \\
\hline Congenital vitium cordis & $3.58 \%$ & $3.80 \%$ & $1.15 \%$ & $.94 \%$ & $1.33 \%$ & $1.15 \%$ & $3.68 \%$ & $1.05 \%$ & $1.24 \%$ \\
\hline Pes calcaneovalgus & $.00 \%$ & $.66 \%$ & $.81 \%$ & $1.28 \%$ & $.75 \%$ & $1.23 \%$ & $.31 \%$ & $1.04 \%$ & $.98 \%$ \\
\hline Pes equinovarus & $.45 \%$ & $1.16 \%$ & $1.32 \%$ & $1.66 \%$ & $1.25 \%$ & $1.62 \%$ & $.78 \%$ & $1.48 \%$ & $1.43 \%$ \\
\hline Syndactyly & $.15 \%$ & $.00 \%$ & $.12 \%$ & $.09 \%$ & $.12 \%$ & $.09 \%$ & $.08 \%$ & $.11 \%$ & $.10 \%$ \\
\hline Polydactyly & $.00 \%$ & $.17 \%$ & $.07 \%$ & $.16 \%$ & $.07 \%$ & $.16 \%$ & $.08 \%$ & $.11 \%$ & $.11 \%$ \\
\hline Brachydactyly & $.00 \%$ & $.00 \%$ & $.02 \%$ & $.00 \%$ & $.02 \%$ & $.00 \%$ & $.00 \%$ & $.01 \%$ & $.01 \%$ \\
\hline Luxatio coxae congenita & $.00 \%$ & $.00 \%$ & $.00 \%$ & $.04 \%$ & $.00 \%$ & $.04 \%$ & $.00 \%$ & $.02 \%$ & $.02 \%$ \\
\hline Dysplasia coxae congenita & $.00 \%$ & $.17 \%$ & $.08 \%$ & $.08 \%$ & $.08 \%$ & $.09 \%$ & $.08 \%$ & $.08 \%$ & $.08 \%$ \\
\hline Retentio testis & $1.49 \%$ & $.00 \%$ & $1.00 \%$ & $.00 \%$ & $1.04 \%$ & $.00 \%$ & $.78 \%$ & $.52 \%$ & $.54 \%$ \\
\hline Hydrocele testis & $.00 \%$ & $.00 \%$ & $.39 \%$ & $.00 \%$ & $.36 \%$ & $.00 \%$ & $.00 \%$ & $.20 \%$ & $.18 \%$ \\
\hline Gastroschisis & $.15 \%$ & $.00 \%$ & $.00 \%$ & $.01 \%$ & $.01 \%$ & $.01 \%$ & $.08 \%$ & $.01 \%$ & $.01 \%$ \\
\hline Chelioschisis & $.00 \%$ & $.00 \%$ & $.06 \%$ & $.03 \%$ & $.06 \%$ & $.02 \%$ & $.00 \%$ & $.04 \%$ & $.04 \%$ \\
\hline Cheliognathopalatoschisis & $.00 \%$ & $.00 \%$ & $.05 \%$ & $.04 \%$ & $.05 \%$ & $.04 \%$ & $.00 \%$ & $.04 \%$ & $.04 \%$ \\
\hline Palatoschisis & $.00 \%$ & $.17 \%$ & $.04 \%$ & $.01 \%$ & $.03 \%$ & $.02 \%$ & $.08 \%$ & $.03 \%$ & $.03 \%$ \\
\hline Multiple congenital anomalies & $.45 \%$ & $.17 \%$ & $.01 \%$ & $.00 \%$ & $.05 \%$ & $.01 \%$ & $.31 \%$ & $.01 \%$ & $.03 \%$ \\
\hline Hydrocephalus & $.60 \%$ & $.17 \%$ & $.05 \%$ & $.01 \%$ & $.09 \%$ & $.02 \%$ & $.39 \%$ & $.03 \%$ & $.06 \%$ \\
\hline Dandy-Walker syndrome & $.00 \%$ & $.00 \%$ & $.01 \%$ & $.00 \%$ & $.01 \%$ & $.00 \%$ & $.00 \%$ & $.01 \%$ & $.01 \%$ \\
\hline Torticollis & $.00 \%$ & $.17 \%$ & $.06 \%$ & $.08 \%$ & $.06 \%$ & $.09 \%$ & $.08 \%$ & $.07 \%$ & $.07 \%$ \\
\hline Hypoplasia mandibular & $.00 \%$ & $.00 \%$ & $.02 \%$ & $.00 \%$ & $.02 \%$ & $.00 \%$ & $.00 \%$ & $.01 \%$ & $.01 \%$ \\
\hline Congenital diaphragmatic hernia & $.15 \%$ & $.00 \%$ & $.02 \%$ & $.01 \%$ & $.03 \%$ & $.01 \%$ & $.08 \%$ & $.02 \%$ & $.02 \%$ \\
\hline Microcephaly & $.00 \%$ & $.17 \%$ & $.01 \%$ & $.00 \%$ & $.01 \%$ & $.01 \%$ & $.08 \%$ & $.01 \%$ & $.01 \%$ \\
\hline
\end{tabular}


Table 1. Continued

\begin{tabular}{|c|c|c|c|c|c|c|c|c|c|}
\hline \multirow{2}{*}{ Congenital anomaly } & \multicolumn{2}{|c|}{$\begin{array}{c}\text { Prematurely born } \\
\text { newborns }\end{array}$} & \multicolumn{2}{|c|}{$\begin{array}{l}\text { Full term } \\
\text { newborns }\end{array}$} & \multicolumn{2}{|c|}{ Total } & \multicolumn{2}{|c|}{ Total } & \multirow[b]{2}{*}{ Total } \\
\hline & M & $\mathbf{F}$ & $\mathbf{M}$ & $\mathbf{F}$ & M & $\mathbf{F}$ & $\begin{array}{c}\text { Prematurely } \\
\text { born } \\
\text { newborns }\end{array}$ & $\begin{array}{l}\text { Full term } \\
\text { newborns }\end{array}$ & \\
\hline Clynodactyly & $.00 \%$ & $.00 \%$ & $.01 \%$ & $.00 \%$ & $.01 \%$ & $.00 \%$ & $.00 \%$ & $.01 \%$ & $.01 \%$ \\
\hline Hypospadias scrotalis & $.00 \%$ & $.00 \%$ & $.01 \%$ & $.00 \%$ & $.01 \%$ & $.00 \%$ & $.00 \%$ & $.01 \%$ & $.01 \%$ \\
\hline Spinal dysraphism & $.00 \%$ & $.00 \%$ & $.01 \%$ & $.00 \%$ & $.01 \%$ & $.00 \%$ & $.00 \%$ & $.01 \%$ & $.01 \%$ \\
\hline Ventriculomegaly & $.45 \%$ & $.00 \%$ & $.00 \%$ & $.00 \%$ & $.03 \%$ & $.00 \%$ & $.24 \%$ & $.00 \%$ & $.02 \%$ \\
\hline Aplasia cutis congenita & $.00 \%$ & $.00 \%$ & $.01 \%$ & $.01 \%$ & $.01 \%$ & $.01 \%$ & $.00 \%$ & $.01 \%$ & $.01 \%$ \\
\hline Aplasia digiti, II, III et IV manus 1.dex. & $.00 \%$ & $.00 \%$ & $.00 \%$ & $.01 \%$ & $.00 \%$ & $.01 \%$ & $.00 \%$ & $.01 \%$ & $.01 \%$ \\
\hline
\end{tabular}

In the mentioned time period, retrospective analysis identified 20 newborns $(.12 \%)$ with Down syndrome (trisomy 21), and one newborn (.01\%) with Edwards syndrome (trisomy 18), but these chromosomopathies haven't been individually analyzed in this work.

In subsample of live-born full term newborns $(\mathrm{N}=15946)$ total of 788 , and in the subsample of liveborn preterm newborns total of 94 newborns have been identified with some of the analyzed congenital anomalies. The relative frequency of individually analyzed congenital anomalies by sex and belonging to the category of full term and prematurely born newborns are shown in Table 1. By analyzing the distribution of observed congenital anomalies between the full term and prematurely born babies, we noticed significant difference for Congenital vitium cordis, Pes calcaneovalgus, Pes equinovarus, Gastroschisis, Multiple congenital anomalies, Hydrocephalus, Microcephaly, Ventriculomegaly, Craniosynostosis and Schizencephaly. Statistically significant differences in the distribution of anomalies by sex were observed for anomalies Pes calcaneovalgus and Pes eqinovarus (Table 2).

Table 2. Results of t test for observed congenital anomalies in the sample of newborns of Tuzla Canton (Bosnia and Herzegovina)

\begin{tabular}{|c|c|c|c|c|c|c|c|c|}
\hline & $\begin{array}{c}\text { Prematurely } \\
\text { born newborns }\end{array}$ & $\begin{array}{l}\text { Full term } \\
\text { newborns }\end{array}$ & $\mathbf{M}$ & $\mathbf{F}$ & $\begin{array}{c}\text { Premature } \\
\text { M }\end{array}$ & $\underset{\text { F }}{\text { Premature }}$ & $\begin{array}{c}\text { Full term } \\
\quad M\end{array}$ & $\begin{array}{l}\text { Full term } \\
\quad \text { F }\end{array}$ \\
\hline \multirow[t]{2}{*}{ Congenital anomaly } & 1276 & 15946 & 8958 & 8264 & 670 & 606 & 8288 & 7658 \\
\hline & $\mathbf{t}$ & $\mathbf{p}$ & $\mathbf{t}$ & $\mathbf{p}$ & $\mathbf{t}$ & $\mathbf{p}$ & $\mathbf{t}$ & $\mathbf{p}$ \\
\hline Congenital vitium cordis & 8.18 & .00 & 1.06 & .29 & .20 & .84 & 1.28 & .20 \\
\hline Pes calcaneovalgus & 2.54 & .01 & 3.23 & .00 & 2.11 & .04 & 2.94 & .00 \\
\hline Pes equinovarus & 2.02 & .04 & 2.05 & .04 & 1.43 & .15 & 1.79 & .07 \\
\hline Gastroschisis & 2.30 & .02 & .06 & .95 & .95 & .34 & 1.04 & .30 \\
\hline $\begin{array}{l}\text { Multiple congenital } \\
\text { anomalies }\end{array}$ & 6.20 & .00 & 1.25 & .21 & .90 & .37 & .96 & .34 \\
\hline Hydrocephalus & 5.14 & .00 & 1.77 & .08 & 1.23 & .22 & 1.25 & .21 \\
\hline Microcephaly & 2.30 & .02 & .06 & .95 & 1.05 & .29 & .96 & .34 \\
\hline Ventriculomegaly & 6.12 & .00 & 1.67 & .10 & 1.65 & .10 & - & - \\
\hline Craniosynostosis & 3.92 & .00 & 1.81 & .07 & 1.49 & .14 & 1.04 & .30 \\
\hline Schizencephaly & 3.54 & .00 & 1.04 & .30 & 1.05 & .29 & - & - \\
\hline
\end{tabular}

By analyzing the distribution of observed congenital anomalies regarding the age categories of mothers, age group of younger than 21 years old mothers, there were total of 1914 newborns, and 99 of the were diagnosed with some of the observed congenital anomalies. In the age group of mothers between the age of 21 and 35, there were 14238 newborns, 722 of them were diagnosed with some of the observed congenital anomalies. In the age group of mothers older than 35 , there were 1070 newborns and 61 of them were diagnosed with some of the observed congenital anomalies. Table 3 shows a distribution of observed congenital anomalies in newborns of Tuzla Canton regarding the age of mothers with a review of significant differences in their distribution. By analyzing the statistical significance in distribution of anomalies according to the mothers age, significant differences were deteermined for Pes calcaneovalgus and Microcephaly (Table 3). In year 2007, highest absolute frequency of observed anomalies was recorded where 319 newborns with some of the observed anomalies were born. During 2008. that number fell to 275 of newborns with some of the observed congenital anomalies. Decreasing trend continued in 2009 when 178 babies were born with some of the observed congenital anomalies, and the lowest frequency was recorded in 2010 with 131 newborns with some of the observed congenital anomalies (Figure 1). Frequency analysis of congenital anomalies by age (2007-2010) and marital distance is presented for a total sample of 903 newborns with congenital anomalies. 
Table 3. Distribution of observed congenital anomalies in newborns of Tuzla Canton in relation to mother's age group

\begin{tabular}{|c|c|c|c|c|c|c|c|c|c|}
\hline \multirow{4}{*}{ Anomaly } & \multicolumn{3}{|c|}{ Total newborns sample } & \multicolumn{6}{|c|}{ Total newborns sample } \\
\hline & \multicolumn{3}{|c|}{ Age group } & \multicolumn{6}{|c|}{ Comparison according to age groups } \\
\hline & \multirow{2}{*}{$\begin{array}{c}\text { to } 20 \\
\mathrm{~N}=1914\end{array}$} & \multirow{2}{*}{$\begin{array}{c}21-35 \\
\mathrm{~N}=14238\end{array}$} & \multirow{2}{*}{$\begin{array}{l}\text { over } 35 \\
\mathrm{~N}=1070\end{array}$} & \multicolumn{2}{|c|}{ to $20-21-35$} & \multicolumn{2}{|c|}{ to 20-over 35} & \multicolumn{2}{|c|}{ 21-35-over 35} \\
\hline & & & & t & $\mathbf{p}$ & $\mathbf{t}$ & $\mathbf{p}$ & $\mathbf{t}$ & $\mathbf{p}$ \\
\hline Congenital vitium cordis & $1.25 \%$ & $1.24 \%$ & $1.31 \%$ & .07 & .95 & .13 & .90 & .21 & .84 \\
\hline Pes calcaneovalgus & $1.52 \%$ & $.91 \%$ & $1.03 \%$ & 2.54 & .01 & 1.12 & .27 & .40 & .69 \\
\hline Pes equinovarus & $1.31 \%$ & $1.45 \%$ & $1.40 \%$ & .49 & .63 & .22 & .83 & .12 & .91 \\
\hline Syndactyly & $.05 \%$ & $.10 \%$ & $.28 \%$ & .62 & .53 & 1.63 & .10 & 1.72 & .08 \\
\hline Polydactyly & $.00 \%$ & $.12 \%$ & $.19 \%$ & 1.51 & .13 & 1.90 & .06 & .60 & .55 \\
\hline Brachydactyly & $.00 \%$ & $.01 \%$ & $.00 \%$ & .52 & .60 & - & - & .39 & .70 \\
\hline Luxatio coxae congenita & $.00 \%$ & $.02 \%$ & $.00 \%$ & .64 & .53 & - & - & .47 & .63 \\
\hline Dysplasia coxae congenita & $.16 \%$ & $.08 \%$ & $.00 \%$ & 1.11 & .27 & 1.30 & .20 & .91 & .36 \\
\hline Retentio testis & $.37 \%$ & $.57 \%$ & $.47 \%$ & 1.13 & .26 & .42 & .67 & .43 & .67 \\
\hline Hydrocele testis & $.16 \%$ & $.18 \%$ & $.28 \%$ & .25 & .80 & .72 & .47 & .71 & .48 \\
\hline Gastroschisis & $.00 \%$ & $.01 \%$ & $.00 \%$ & .52 & .60 & - & - & .39 & .70 \\
\hline Chelioschisis & $.00 \%$ & $.04 \%$ & $.09 \%$ & .90 & .37 & 1.34 & .18 & .76 & .45 \\
\hline Cheliognathopalatoschisis & $.05 \%$ & $.04 \%$ & $.09 \%$ & .37 & .72 & .42 & .68 & .93 & .35 \\
\hline Palatoschisis & $.10 \%$ & $.02 \%$ & $.00 \%$ & 1.95 & .05 & 1.06 & .29 & .47 & .63 \\
\hline $\begin{array}{l}\text { Multiple congenital } \\
\text { anomalies }\end{array}$ & $.00 \%$ & $.03 \%$ & $.09 \%$ & .73 & .46 & 1.34 & .18 & 1.14 & .25 \\
\hline Hydrocephalus & $.05 \%$ & $.06 \%$ & $.00 \%$ & .18 & .86 & .75 & .45 & .82 & .41 \\
\hline Dandy-Walker syndrome & $.00 \%$ & $.01 \%$ & $.00 \%$ & .37 & .71 & - & - & .27 & .78 \\
\hline Torticollis & $.00 \%$ & $.07 \%$ & $.19 \%$ & 1.16 & .25 & 1.90 & .06 & 1.32 & .19 \\
\hline Hypoplasia mandibular & $.00 \%$ & $.01 \%$ & $.00 \%$ & .37 & .71 & - & - & .27 & .78 \\
\hline $\begin{array}{l}\text { Congenital diaphragmatic } \\
\text { hernia }\end{array}$ & $.00 \%$ & $.02 \%$ & $.09 \%$ & .64 & .53 & 1.34 & .18 & 1.41 & .16 \\
\hline Microcephaly & $.00 \%$ & $.01 \%$ & $.09 \%$ & .37 & .71 & 1.34 & .18 & 2.39 & .02 \\
\hline Clynodactyly & $.00 \%$ & $.01 \%$ & $.00 \%$ & .37 & .71 & - & - & .27 & .78 \\
\hline Hypospadias scrotalis & $.00 \%$ & $.01 \%$ & $.00 \%$ & .37 & .71 & - & - & .27 & .78 \\
\hline Spinal dysraphism & $.00 \%$ & $.01 \%$ & $.00 \%$ & .37 & .71 & - & - & .27 & .78 \\
\hline Ventriculomegaly & $.05 \%$ & $.01 \%$ & $.00 \%$ & 1.15 & .25 & .75 & .45 & .39 & .70 \\
\hline Aplasia cutis congenita & $.05 \%$ & $.01 \%$ & $.00 \%$ & 1.67 & .10 & .75 & .45 & .27 & .78 \\
\hline $\begin{array}{l}\text { Aplasia digiti, II, III et IV } \\
\text { manus 1.dex. }\end{array}$ & $.00 \%$ & $.01 \%$ & $.00 \%$ & .37 & .71 & - & - & .27 & .78 \\
\hline Craniosynostosis & $.00 \%$ & $.01 \%$ & $.09 \%$ & .52 & .60 & 1.34 & .18 & 1.79 & .07 \\
\hline Trigoneocephaly & $.05 \%$ & $.01 \%$ & $.00 \%$ & 1.67 & .10 & .75 & .45 & .27 & .78 \\
\hline Schizencephaly & $.00 \%$ & $.01 \%$ & $.00 \%$ & .37 & .71 & - & - & .27 & .78 \\
\hline
\end{tabular}

By analyzing the distribution of observed congenital anomalies according to the parameter of marital distance, it was determined that 420 newborns detected with some of the observed anomalies have parents with the same place of birth, that is with marital distance of 0 (zero) $\mathrm{km}$. Decrease of frequency of congenital anomalies is detected along with the increase of marital distance, and with the marital distance of $>101 \mathrm{~km}$ there is a significant decrease of newborns with some of the observed congenital anomalies (Figure 2).

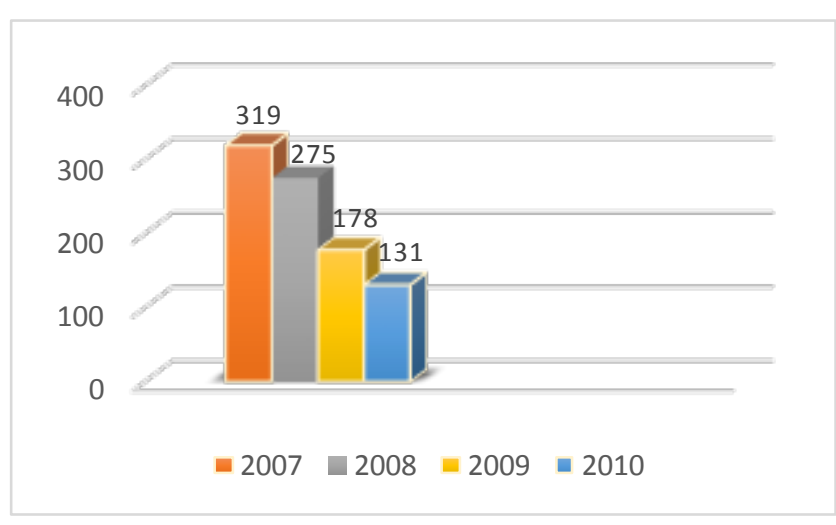

Figure 1. Absolute frequency of observed congenital anomalies in the total sample of newborns per year (2007-2010) 


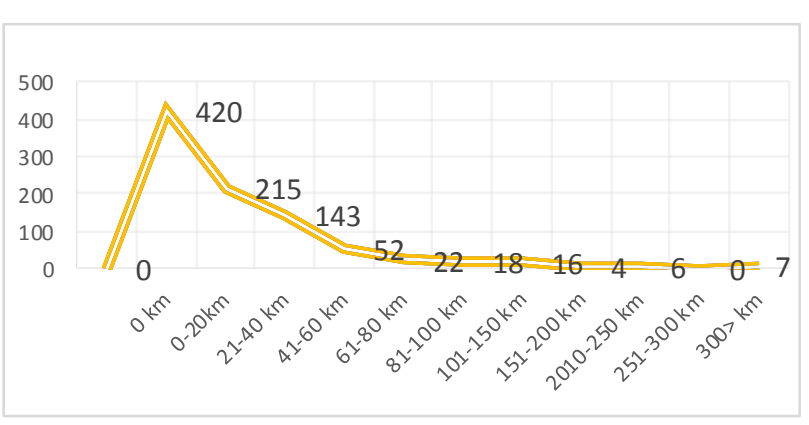

Figure 2. Absolute frequency of observed congenital anomalies in total sample of newborns of Tuzla Canton by marital distance categories

Statistically significant differences in total frequency of all observed congenital anomalies, most commonly appear in comparison of other categories of distance with marital distance of $0 \mathrm{~km}$.

\section{DISCUSSION}

By analyzing the frequency of observed congenital anomalies in total sample $(\mathrm{N}=17223)$ of newborns in Tuzla Canton, 903 children were registered with some of the observed congenital anomalies (every 19th nerwborn). Especially high was the percentage of newborns with observed congenital anomalies in sub sample of prematurely born babies (every 12th child). Researches of frequency of congenital anomalies in newborns of Banja Luka area, frequency of $5.18 \%$ was determined (Terzic, 1986). In the time span of 8 years, by using the retrospective analysis of 41395 births in Clinic for Gynecology and Obstetrics of University Clinical Center in Tuzla (Skokic and Nevacinovic, 2005) recorded 647 newborns with congenital anomalies, with incidence of 1:63.97 and prevalence of 15.62 in 1000 live born babies. In a retrospective research of newborns in Nigeria, there was a prevalence of congenital anomalies of $2.8 \%$ (Obu and associates, 2012.). Božinović and associates (2006) determined frequency of newborns in Prokuplje (Serbia) of $4.00 \%$. Similar results were determined in Sremska Mitrovica by Jovanovic and associates (2003) where they determined the frequency of congenital anomalies of $4.43 \%$. Same authors researched the frequency of congenital anomalies in maternity hospital in Ruma (Serbia) in period between 1997 and 2002 and found that the frequency was $3.50 \%$. Tayebi and associates (2010) studied the influence of blood relation of parents on the occurrence of congenital anomalies in newborns and correlation of inbreeding coefficient with anomalies in total sample and they determined the frequency of congenital anomalies of $3.76 \%$. Share of anomalies from the marriages in blood relation was $2.8 \%$, and in marriages without blood relation frequency was $.90 \%$. That proved the increased frequency of births of children with congenital anomalies in marriages connected with inbreeding. By researching the frequency of congenital anomalies in newborns in Central India (Taksande and associates 2010) frequency of congenital anomalies of $1.91 \%$ was determined. Same research determined that prematurely born children and low birth weight are factors indicating the higher risk for congenital anomalies. Vaktskjold and associates (2011) were researching the frequency of congenital anomalies in newborns in pregnant women who were professionally exposed to some chemicals (organic solvents) and pregnant women without this negative exogenous factor. Relative frequency of congenital anomalies in group exposed to negative influence of organic solvents was $4.4 \%$ and without this negative factor it was 3.9\%. Yasir and associates (2011) in the research conducted in Egypt determined the total frequency of congenital anomalies of $2.06 \%$. Frequency of congenital anomalies in total sample in Tuzla Canton and its subsamples, even though very high, it still fits in the extent of variation of this parameter's value in earlier researches of Bosnian and Herzegovinian and world population. Regarding the gender distribution in total sample of newborns in Tuzla Canton, higher frequencies were detected in male newborns $(5.64 \%)$, while the female newborns frequency was $4.82 \%$. Yasir and associates (2011) also find the higher frequency in male newborns in their research of anomalies in newborns in Egypt, relative frequency in male newborns in relation to female newborns was 1.7:1. In research of frequency of some anomalies according to gender in total sample of newborns in TK, statistically less significant differences were noted in congenital anomalies Pes calcaneovalgus and Pes equinovarus. By results comparison, detected frequencies in this paper do not deviate from the frequencies found by other authors. Mutual relation of frequency of congenital anomalies and the age of mother was the research subject of many authors. By analyzing the relative frequency in total sample of Tuzla Canton newborns, the highest frequency was detected in the age group of mothers older than 35 years $(5.70 \%)$ and the lowest in the group of mother aged between 21 and 35 (5.07\%). In both genders the highest frequency of congenital anomalies is detected in mothers aged over 35. Increase in frequency of anomalies with increase in age of mother is registered for following anomalies: Congenital vitium cordis, Pes equinovarus, Syndactyly, Polydactyly, Hydrocele testis, Chelioschisis, Cheliognathopalatoschisis, Multiple congenital anomalies, Torticollis, Congenital diaphragmatic hernia, Microcephaly, Craniosynostosis (Table 3). By researching the influence of the age of mother on distribution of anomalies in newborns of Banja Luka area, highest frequency $(8.99 \%)$ was registered in the offspring of mothers aged 36 to 40 (Terzic, 1987). In the same research, the increase of frequency in combination with age of mother is registered only for Down syndrome: .00\% (younger than 20$), .07 \%(21-25), .13 \%(26-30), .14 \%(31-35)$, $1.29 \%(36-40), 1.83 \%$ (over 40 ), which proves the conclusion that the frequency of chromosomopathies is in positive correlation with the age of mother. 
Muga and associates (2009) by analyzing the frequency of congenital anomalies in newborns in Kenya have determined the absolute frequency of 112 affected newborns with some of the congenital anomalies. The highest frequency of anomalies was noted in newborns with mothers aged between 20 and 24, with 36 affected newborns with some of the congenital anomalies. As a possible reason for such distribution they cited the way of life of mothers, that is the negative influence of exogenous factors. Perveen and Tayebi (2007) in their research have determined that the highest frequency of congenital anomalies occurs in the offspring of mothers aged between 21 and 30, which collides with all past researches. They also concluded that the highest number of anomalies is present in children in marriages with blood relation, and the most common anomaly is the defective neural tube. Singh and Ravinder (2009) by analyzing the congenital anomalies in India have concluded that anomalies occur more often in offspring of mothers aged $>35(9.01 \%)$ in relation to offspring of mothers $<20(4.93 \%)$. According to the research of Taksande and associates (2010) in newborns in Central India, congenital anomalies most often occur in offspring of mothers older than $30(3.60 \%)$, then in offspring of mothers aged between 21 and 25 (2.12\%). Somewhat lower frequency $(1.44 \%)$ occurs in offspring of mothers aged between 26 and 30, and the lowest frequency is recorded in offspring of mothers younger than $20(.35 \%)$. By comparing our results of influence of the age of mother on the occurrence of congenital anomalies in newborns in Tuzla Canton with the data provided by the other authors, we can conclude that congenital anomalies most often occur in mothers older than 35 years. Results of our research fit into extent of values of variation of this parameter with reference data from the literature. Most of the researches relates to the influence of the age of the mother on anomalies frequency while there is very little reliable data about the influence of father's age on the frequency of anomalies. Terzic (1987) claims that in the newborns of Banja Luka area, the highest frequency of congenital anomalies is recorded in fathers aged between 21 and $30(11.50 \%)$. Relatively high frequency is registered in fathers older than $36(7.74 \%)$, and in fathers over 40 $(8.20 \%)$. Based on this research it can be concluded that in the offspring of fathers aged between 26 and 40 and older, there is an increase in frequency of congenital anomalies, which leads to assumption that the age of father probably has some influence on the frequency of congenital anomalies. During the 2007, in the area of Tuzla Canton, 319 newborns were born with congenital anomalies. In 2008, 275 newborns were born. From 2009 to 2010 that number decreases significantly. In 2009, 178 anomalies were diagnosed, and in 2010 that number fell to 131 . The decrease in the frequency of congenital anomalies in the analyzed time period by years, indicates the positive effects of the application of multidisciplinary approaches in early prenatal diagnosis, by combining some cytogenetic and clinical procedures. In the time span covered with this research $(01.01 .2007-31.12 .2010$.) in
Cytogenetic Laboratory for Molecular Diagnostics of Policlinic for Diagnostics of University Clinical Center Tuzla (UKC Tuzla), 616 amniocenteses were performed. By analyzing the distribution of frequency according to marital distance parameter, it can be concluded that highest number of occurrences of congenital anomalies appear in the marital distance category " $0 \mathrm{~km}$ ". In marital distance category "251$300 \mathrm{~km}$ ", there is no congenital anomalies and in the highest $300+\mathrm{km}$ category there are 7 congenital anomalies. Significant differences in total frequency of all observed congenital anomalies are most often the combination of category of marital distance " $0 \mathrm{~km}$ " and some other category which proves the conclusions of other authors who stated that frequency of many pathological and normal variations of different qualitative hereditary characteristics in population, depends in a large degree on the level of openness of propagation system. Interesting finding of studying the distribution of congenital anomalies in categories of marital distance of newborns in Banja Luka are where also the most observed anomalies occur in the " $0 \mathrm{~km}$ " category, and in the highest categories ("251$300 \mathrm{~km}$ " and " $300+\mathrm{km}$ ") there were far less anomalies (Hadziselimovic and Terzic, 1986).

\section{CONCLUSIONS}

Complete multidisciplinary approach in prenatal diagnostics will result in rational planning of diagnostic procedures with the goal of better and quicker diagnosing in the early prenatal period, in order to reduce the frequency of congenital anomalies. By combining clinical and genetic methods, these results can be achieved. Presented concept is formulated on the basis of expectation that the results of this research can give a scientific contribution in analysis of frequency of observed anomalies in the examined part of Bosnian and Herzegovinian society. These also can serve as starting basis for further research and establishment of data basis for formation of genetic advisory centers in order to reduce the frequency of congenital anomalies.

\section{REFERENCES}

Bozinovic, D., Mladenovic, I., Bozinovic, N. (2006). Učestalost rađanja dece sa kongenitalnim anomalijama $\mathrm{u}$ porodilištu Prokuplje [Birth frequency of children with congenital anomalies in the maternity hospital Prokuplje]. Glasnik Antropološkog društva Jugoslavije, 41, 465-470.

Garrett, H.E. (1962). Elementarna statistika [Elementary statistics]. Psihološki bilten (specijalno izdanje). Beograd.

Hadziselimovic, R. i Terzic, R. (1986). Relacija između maritalne distance $\mathrm{i}$ učestalosti kongenitalnih anomalija u stanovništvu banjalučke regije [Relations between marital distance and frequency of the congenital anomalies in the population of Banja Luka region]. Godišnjak Biološkog instituta, 38, 55-71. Jovanovic-Privrodski,J.,Popic-Paljic,F.,Kavecan,I.,Milic,S.,Loncar, S., Potrebic, N., Dosen, B., Dincic, D., Koviljac-Mitrovic, M. (2003). EUROCAT na teritoriji Srema u periodu pre i posle NATO bombardovanja (1997-2002.godine). [EUROCAT for area of Srem in period before and after NATO bombing, $1997-$ 2002. years]. Timočki medicinski glasnik, Glasilo Srpskog lekarskog društvo, podružnica Zaječar, 28(3-4),75-78. 
Muga, R. O., Mumah, S.C.J. i Juma, P. A. (2009). Congenital Malformations Among newborns in Kenya. African Journal of Food, Agriculture, Nutrition and Development, 9(3), 814829 .

Obu, H.A., Chinawa, J.M., Uleanya, N.D., Adimora, G.N., Obi, I.E. (2012). Congenital Malformations Among Newborns admitted in the Neonatal Unit of a tertiary Hospital in Enugu, South-East Nigeria retrospective study. BMC Res Notes. 2012 Jul 10; 5:177. doi: 10.1186/1756-0500-5-177.

Perveen, F. Tyyab, S. (2007). Frequency and Pattern of Distribution of Congenital Anomalies in the Newborn and Associated Maternal Risk Factors. J Coll Physicians Surg Pak, 17(6), 340-343.

Singh, A., Gupta R.K. (2009). Pattern of Congenital Anomalies in Newborn: A Hospital Based Prospective Study. JK SCIENCE, 11(1), January-March. 34-36. www.jkscience. org.

Skokic, F. i Nevacinovic, E. (2005). Epidemiological and clinical characteristics of congenital anomalies in Tuzla Canton, Bosnia and Herzegovina. Gynaecologia et Perinatologia, 14(2), 99-103.

Taksande, A., Vilhekar, K., Chaturvedi, P. i Jain, M. (2010). Congenital malformations at birth in Central India: A rural medical college hospital based data. Indian Journal Human of Genetics, 16(3), 159-163.
Tayebi, N., Yazdani, K., Naghshin, N. (2010). The Prevalence of Congenital Malformations and its Correlation with Consanguineous Marriages. Oman Medical Journal, 25(1), 37-40.

Terzic, R. (1986). Frekvencija nekih kongenitalnih anomalija u uzorku novorođenčadi banjalučke regije [Frequency of some congenital anomalies among the new born children in the region Banjaluka]. Glasnik Antropološkog društva Jugoslavije, 9, 131-158.

Terzic, R. (1987). Frekvencija nekih kongenitalnih anomalija u uzorku novorođenčadi banjalučke regije u ovisnosti od starosti roditelja [Frequency of some congenital anomalies among the new born children in the region Banjaluka regarding the age of parents]. God. Biol. inst. Sarajevo, 41, 81-95.

Vaktskjold, A., Talykova, LJ.V. and Nieboer, E. (2011). Congenital Anomalies in Newborns to Women Employed in Jobs With Frequent Exposure to Organic Solvents - A register-Based Prospective Study. BMC Pregnancy and Childbirth. Oct 27;11:83, DOI: 10.1186/1471-2393-11-83.

Yasir, A.M., Rabah, M.S., Amal A.S.S. , Maher, M.A. (2011). Chromosomal study in newborn infants with congenital anomalies in Assiut University hospital : Cross-sectional study. The Egyptian Journal of Medical Human Genetics, 12 (1), 79-90.

https://www.who.int/news-room/fact-sheets/detail/congenitalanomalies (03.05.2020.) 